\title{
Pathogenic Diversity of Xanthomonas campestris pv. poae within the Genus Poa*
}

\author{
Tomoki NISHINO** and Takane FUJIMORI**
}

\begin{abstract}
The diversity of pathogenicity of Xanthomonas campestris pv. poae, the causal agent of bacterial wilt in the genus Poa, was studied. Strains of $X . c$. pv. poae were distinguishable into three groups, according to differences in their pathogenicity against Poa species. Group 1, represented by strain JT-P192, caused mild wilt and a pale yellow appearance in leaves of annual bluegrass and supina bluegrass. Group 2, represented by strain JT-P482, was pathogenic to annual bluegrass, rough bluegrass and supina bluegrass, but caused only wilt symptoms. Group 3 included the type strain of $X$. c. pv. poae, which caused only a wilt in annual bluegrass, rough bluegrass, supina bluegrass and big bluegrass. Compatible and incompatible relationships were evaluated from the symptoms on infected plants and from bacterial multiplication in the lowest part of the culm after leaf clipping-inoculation.
\end{abstract}

(Received July 7, 1997 ; Accepted October 6, 1997)

Key words : pathogenicity, multiplication, Poa genus, Xanthomonas campestris pv. poae.

\section{INTRODUCTION}

Xanthomonas campestris pv. poae, the causal agent of bacterial wilt of Poa species, is distributed throughout Europe $^{5,6,18)}$, the U. S. ${ }^{12,16)}$ and Japan ${ }^{10-12)}$. This pathogen is localized in the vascular systems of host plants. $X . c$. pv. poae from Switzerland was first reported by Egli and Schmidt ${ }^{6)}$; rough bluegrass (Poa trivialis L.) was very susceptible, whereas annual bluegrass (P. annua L.) was only moderately susceptible. Recently, bacterial wilt of annual bluegrass has also been found in the U.S. ${ }^{16)}$ and in Japan $^{10,11)}$. Identified as $X . c . p v$. poae, these newly found bacteria are strongly aggressive on annual bluegrass but not on rough bluegrass ${ }^{12)}$ and are distinguishable into two groups according to the symptoms or disease severity in annual bluegrass ${ }^{12)}$. One group causes mild wilt and/or pale yellow discoloration limited to leaf blades, and the other causes severe systemic wilt.

Because $X . c$. pv. poae causes a severe wilt on annual bluegrass, it has been investigated as a biological control agent against annual bluegrass in the U. S. ${ }^{8,19)}$ and in Japan $^{1,2,13,14)}$. Annual bluegrass is a problematic weed due to the lack of selective herbicides for its control in intensively managed turfs ${ }^{4}$. About 500 species of the Poa genus are distributed throughout the world ${ }^{15}$, including beneficial turf grasses, such as Kentucky bluegrass ( $P$. pratensis L.). However, the pathogenicity of newly found strains of $X . c$. pv. poae on $P o a$ species has not been investigated.

To elucidate the pathogenic diversity of $X . c$. pv. poae among the Poa genus, we studied symptoms on 23 clutivars from nine species of $P o a$ inoculated with 10 strains of $X . c$. pv. poae, and measured bacterial multiplication in the plants after leaf clipping-inoculation ${ }^{9)}$.

\section{MATERIALS AND METHODS}

Bacteria and plants The bacterial strains tested in this study are listed in Table 1. The American strains, MB218, MB245 and MB291, were provided by the Mycogen Corporation, and the type strain of $X . c$. pv. poae ATCC33804 was provided by the American Type Culture Collection (ATCC).

Plants for inoculation tests included two cultivars of annual bluegrass (originating in Japan and in the UK.), six cultivars of rough bluegrass (cv. Omega, cv. Sabre, cv. Colt, cv. Laser, cv. Dasas and one originating in the UK.), nine cultivars of Kentucky bluegrass ( $P$. pratensis L. cv. Ken Blue, cv. Merit, cv. Coventry, cv. Adelphi, cv. Baron, cv. Raml, cv. Banff, cv. Nassau and one originating in the UK.), supina bluegrass ( $P$. supina Schrad. cv. Supina), big bluegrass ( $P$. ampla Merr. cv. Sherman), Canada bluegrass ( $P$. compressa L. cv. Ruebens), sandberg bluegrass ( $P$. secunda Presl cv. VNS), bulbous bluegrass ( $P$. bulbosa L., cultivar unknown) and alpine bluegrass ( $P$. alpina L., cultivar unknown). Annual bluegrass originating in Japan was provided by Utsunomiya

* A part of this work was reported at the Annual Meeting of the Phytopathological Society of Japan in 1997.

** Plant Protection Research Laboratory, Japan Tobacco Inc., 6-2 Umegaoka, Aoba-ku, Yokohama 227-8512, Japan 日本たばこ産業株式会社植物保護開発センター 
Table 1. Strains of Xanthomonas campestris pv. poae used in this study

\begin{tabular}{|c|c|c|c|}
\hline Strains & $\begin{array}{c}\text { Original } \\
\text { host plant }\end{array}$ & Locality & $\begin{array}{c}\text { Other features } \\
\text { (Reference) }\end{array}$ \\
\hline JT-P192 & $\begin{array}{l}\text { Annual } \\
\text { bluegrass }\end{array}$ & $\begin{array}{l}\text { Aomori Pref. } \\
\text { in Japan }\end{array}$ & Group 1 (12) \\
\hline JT-P195 & do & do & do (this study) \\
\hline JT-P196 & do & $\begin{array}{l}\text { Aichi Pref. } \\
\text { in Japan }\end{array}$ & do (12) \\
\hline JT-P481 & do & $\begin{array}{l}\text { Tochigi Pref. } \\
\text { in Japan }\end{array}$ & Group 2 (12) \\
\hline JT-P482 & do & $\begin{array}{l}\text { Kanagawa } \\
\text { Pref. } \\
\text { in Japan }\end{array}$ & do (12) \\
\hline JT-P484 & do & $\begin{array}{l}\text { Chiba Pref. } \\
\text { in Japan }\end{array}$ & do (12) \\
\hline MB218 ${ }^{a}$ & do & U.S.A & do (12) \\
\hline MB245 & do & do & do (12) \\
\hline MB291 & do & do & $\begin{array}{l}\text { Group } 1 \text { (this } \\
\text { study) }\end{array}$ \\
\hline $\begin{array}{l}\text { ATCC33804 } \\
(\mathrm{Xg} 724)\end{array}$ & $\begin{array}{l}\text { Rough } \\
\text { bluegrass }\end{array}$ & Switzerland & $\begin{array}{l}\text { Group } 3 ; \\
\text { Type strain } \\
\text { of } X . c . \text { pv. } \\
\text { poae ; }(6)\end{array}$ \\
\hline
\end{tabular}

a) Strain MB218, MB245 and MB291 were provided by Mycogen Corp.

b) ATCC: American Type Culture Collection.

University. The other species of $P o a$ were provided by the Mycogen Corporation, except for plants originating in the UK., which were purchased from Herbiseed (Wokingham, England, UK.).

Inoculation Seeds were sown in plastic pots of organic soil and grown in a greenhouse at $25^{\circ} \mathrm{C} / 20^{\circ} \mathrm{C}$ (day/night) for 4 weeks.

Bacteria were cultured in $\mathrm{YNB}^{12)}$ liquid medium at $28^{\circ} \mathrm{C}$ for 2 days on a rotary shaker until the early stationary growth phase. Bacterial cells were then collected by centrifugation and resuspended in equal volumes of sterile distilled water. The bacterial suspensions were diluted to a final concentration of $10^{8} \mathrm{cfu} / \mathrm{ml}$, by comparison with an absorption curve at $575 \mathrm{~nm}$, to prepare the inocula. Plants, 4 weeks after sowing, were inoculated by means of leaf clipping-inoculation ${ }^{9}$. The inoculated plants were all grown under the same greenhouse conditions, both to observe disease severity and to investigate bacterial multiplication in the plants.

Measurement of disease severity Disease severity in inoculated plants was assessed according to the following five criteria : A : severe attack, all plants died ; $\mathrm{B}$ : heavy attack, plants wilted with only $30 \%$ remaining green; C: moderate attack, plants wilted but later regenerated, growing pale yellow new leaves; D : slight attack, only clip-inoculated leaves wilted; E : no attack, plants remained entirely healthy. The disease index was calculated according to the following formula :

$$
\begin{aligned}
& \text { Disease index (\%) } \\
& =\frac{A \times 4+B \times 3+C \times 2+D \times 1+E \times 0}{(A+B+C+D+E) \times 4} \times 100
\end{aligned}
$$

Measurement of bacterial multiplication in plants Two methods were used to assess bacterial multiplication in plants after leaf clipping-inoculation. To count the number of viable bacteria in the vascular systems of inoculated plants, $5 \mathrm{~mm}$ lengths of tissue samples from the inoculated leaf tips and the lowest parts of the culm were collected from inoculated plants which had been surface-sterilized by wiping with cotton dipped in $70 \%$ ethanol. Collected tissue samples were cut into five pieces in $200 \mu$ l of sterile distilled water and shaken gently for $c a .30 \mathrm{~min}$ to isolate the bacteria in the vascular systems. The suspensions were diluted serially and spread on to $\mathrm{YNA}^{12)}$ plates containing $200 \mu \mathrm{g} / \mathrm{ml}$ of cycloheximide to count the number of viable cells. The other method was simply microscopically checking for bacterial exudation from vascular tissue samples excised from inoculated plants set in a drop of water.

\section{RESULTS}

\section{Aggressiveness of each strain against Poa species}

Four weeks after inoculation, annual bluegrass, rough bluegrass, supina bluegrass and big bluegrass showed symptoms from some strains of $X$. c. pv. poae. However, Kentucky bluegrass, Canada bluegrass, sandberg bluegrass, bulbous bluegrass and alpine bluegrass showed no typical symptoms from any of the tested strains (Table 2 ). When the disease index was under 30\%, no typical symptoms were observed. Strain JT-P192 caused heavy symptoms (disease index of about $50 \%$ ) on annual bluegrass and caused moderate symptoms (disease index of about $30 \%$ ) on supina bluegrass and on two cultivars of rough bluegrass (cv. Omega and the one originating in the UK.). Strain JT-P482 caused moderate to heavy symptoms on rough bluegrass and caused plant death in annual bluegrass and supina bluegrass. Strain ATCC33804, the type strain of $X$. c. pv. poae, caused heavy symptoms on rough bluegrass, moderate symptoms on annual bluegrass and supina bluegrass, and caused plant death in big bluegrass.

\section{Multiplication in plants}

The multiplication of three strains of $X . c . p v$. poae in four species of $P o a$ which showed symptoms from some strains of $X . c$. pv. poae was examined. Annual bluegrass originating in the UK., rough bluegrass originating in the UK., supina bluegrass and big bluegrass were used as the test plants. All tested strains of $X$. c. pv. poae (JT-P192, JT-P482 and ATCC33804) multiplied in a similar manner in the inoculated leaf tips of all tested plants (Fig. 1). In the inoculated leaf tips, bacteria multiplied to about $10^{7} \mathrm{cfu} / 5 \mathrm{~mm}$ length of the leaf tissue until 5 days after inoculation, and then the bacterial population declined. This decline of bacterial populations in the inoculated leaf tips was related to the wilt of 
Table 2. Disease severity on Poa species inoculated with different strains of $X$. c. pv. poae

\begin{tabular}{|c|c|c|c|}
\hline \multirow{2}{*}{$\begin{array}{l}\text { Plants inoculated } \\
\text { (origin or cultivar) }\end{array}$} & \multicolumn{3}{|c|}{ Disease index ${ }^{a}(\%)$} \\
\hline & JT-P192 & JT-P482 & ATCC33804 \\
\hline \multicolumn{4}{|l|}{ Annual bluegrass } \\
\hline \multicolumn{4}{|l|}{ Poa апnua } \\
\hline (originating in the UK.) & $58.3 \pm 4.8$ & $100.0 \pm 0.0$ & $36.7 \pm 4.1$ \\
\hline (originating in Japan) & $58.3 \pm 4.7$ & $100.0 \pm 0.0$ & $41.7 \pm 4.7$ \\
\hline \multicolumn{4}{|l|}{ Rough bluegrass } \\
\hline \multicolumn{4}{|l|}{$P$. trivialis } \\
\hline (originating in the UK.) & $30.0 \pm 2.7$ & $46.7 \pm 6.8$ & $51.7 \pm 5.2$ \\
\hline (cv. Omega) & $33.3 \pm 3.1$ & $46.7 \pm 4.8$ & $58.3 \pm 4.7$ \\
\hline (cv. Sabre) & $25.0 \pm 0.0$ & $38.3 \pm 4.1$ & $46.7 \pm 4.8$ \\
\hline (cv. Colt) & $26.7 \pm 1.7$ & $35.0 \pm 3.3$ & $48.3 \pm 4.5$ \\
\hline (cv. Laser) & $28.3 \pm 2.3$ & $38.3 \pm 4.8$ & $48.3 \pm 4.5$ \\
\hline (cv. Dasas) & $28.3 \pm 2.3$ & $38.3 \pm 5.4$ & $70.0 \pm 4.4$ \\
\hline \multicolumn{4}{|l|}{ Kentucky bluegrass } \\
\hline \multicolumn{4}{|l|}{ P. pratensis } \\
\hline (originating in the UK.) & $26.7 \pm 1.7$ & $15.0 \pm 3.3$ & $16.7 \pm 3.1$ \\
\hline (cv. Ken Blue) & $18.3 \pm 3.0$ & $11.7 \pm 3.3$ & $16.7 \pm 3.1$ \\
\hline (cv. Merit) & $25.0 \pm 0.0$ & $21.7 \pm 3.3$ & $20.0 \pm 2.7$ \\
\hline (cv. Coventry) & $15.0 \pm 3.3$ & $13.3 \pm 3.3$ & $11.7 \pm 3.3$ \\
\hline (cv. Adelphi) & $15.0 \pm 3.3$ & $16.7 \pm 4.0$ & $13.3 \pm 3.3$ \\
\hline (cv. Baron) & $25.0 \pm 0.0$ & $16.7 \pm 3.1$ & $18.3 \pm 3.0$ \\
\hline (cv. Raml) & $18.3 \pm 3.0$ & $20.0 \pm 3.6$ & $15.0 \pm 3.3$ \\
\hline (cv. Banff) & $20.0 \pm 2.7$ & $18.3 \pm 3.0$ & $15.0 \pm 3.3$ \\
\hline (cv. Nassau) & $13.3 \pm 3.3$ & $16.7 \pm 4.0$ & $15.0 \pm 3.3$ \\
\hline \multicolumn{4}{|l|}{ Supina bluegrass } \\
\hline \multicolumn{4}{|l|}{ P. supina } \\
\hline (cv. Supina) & $33.3 \pm 3.1$ & $100.0 \pm 0.0$ & $33.3 \pm 3.1$ \\
\hline \multicolumn{4}{|l|}{ Big bluegrass } \\
\hline \multicolumn{4}{|l|}{ P. ampla } \\
\hline (cv. Sherman) & $10.4 \pm 3.7$ & $17.5 \pm 3.8$ & $100.0 \pm 0.0$ \\
\hline \multicolumn{4}{|l|}{ Canada bluegrass } \\
\hline \multicolumn{4}{|l|}{ P. compressa } \\
\hline (cv. Ruebens) & $21.7 \pm 2.3$ & $16.7 \pm 3.1$ & $10.0 \pm 3.3$ \\
\hline \multicolumn{4}{|l|}{ Sandberg bluegrass } \\
\hline \multicolumn{4}{|l|}{$P$. secunda } \\
\hline (cv. VNS) & $6.7 \pm 3.0$ & $20.0 \pm 5.6$ & $15.0 \pm 3.3$ \\
\hline \multicolumn{4}{|l|}{ Bulbous bluegrass } \\
\hline \multicolumn{4}{|l|}{ P. bulbosa } \\
\hline (cultivar unknown) & $25.0 \pm 0.0$ & $23.0 \pm 2.1$ & $16.7 \pm 4.2$ \\
\hline \multicolumn{4}{|l|}{ Alpine bluegrass } \\
\hline \multicolumn{4}{|l|}{ P. alpina } \\
\hline (cultivar unknown) & $6.7 \pm 3.0$ & $6.7 \pm 3.0$ & $13.3 \pm 3.3$ \\
\hline
\end{tabular}

a) Each value is the mean (disease index \pm standard error) of 15 replications of inoculated plants.

leaves. Test bacteria were not able to maintain their populations in the inoculated leaf tips of their host plants, because the inoculated leaf tips dried out 4 weeks after inoculation when inoculated leaves had wilted severely. Typical symptoms were not observed in rough bluegrass which had been inoculated with strain JTP192 or in big bluegrass which had been inoculated with either strain JT-P192 or JT-P482. In these cases, bacterial populations in the inoculated leaf tips did not decline rapidly.

Multiplication in the lowest part of the culm differed in different strain/plant combinations (Fig. 2). Strain JT-P192 was able to multiply in the lowest part of the culm of annual bluegrass and supina bluegrass. Strain JT-P482 was able to multiply in the lowest part of the culm of annual bluegrass, rough bluegrass and supina bluegrass. Strain ATCC33804 was able to multiply in the lowest part of the culm of annual bluegrass, rough bluegrass, supina bluegrass and big bluegrass. In annual bluegrass/pathogen combinations in $5 \mathrm{~mm}$ of tissue segments, strain JT-P482 multiplied to about $1.0 \times 10^{9} \mathrm{cfu}$, strain JT-P192 multiplied to about $1.0 \times 10^{7} \mathrm{cfu}$, and strain ATCC33804 multiplied to about $1.0 \times 10^{4} \mathrm{cfu}$. The multiplication rate of strains in the lowest part of the culm in annual bluegrass was correlated with the plants' disease severity. This relationship between the multipli- 


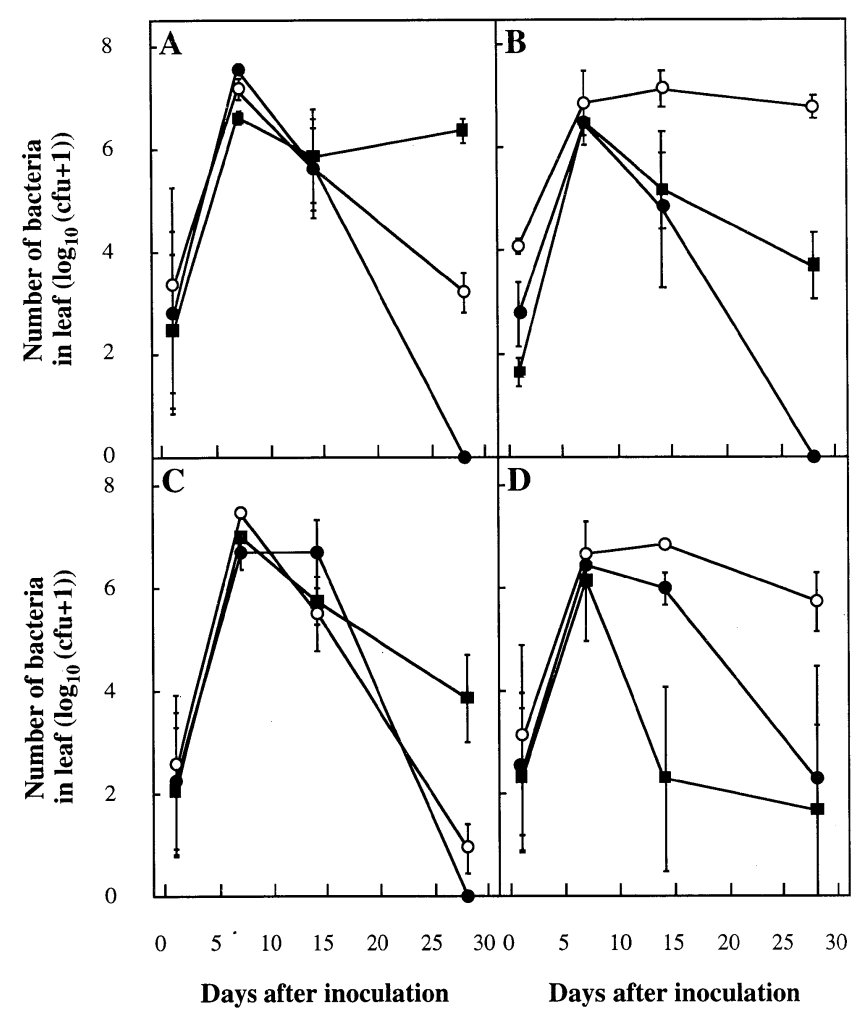

Fig. 1. Multiplication of strains of X.c. pv. poae in 5 $\mathrm{mm}$ sections of leaf tissue from the inoculated leaf tip of Poa species. Annual bluegrass ( $P$. annua) (A), rough bluegrass ( $P$. trivialis) $(\mathrm{B})$, supina bluegrass (P. supina) $(\mathrm{C})$ and big bluegrass $(P$. ampla) (D) were inoculated with $1.0 \times$ $10^{8} \mathrm{cfu} / \mathrm{ml}$ of bacterial suspension of JT-P192 (○), JT-P482 (-) and ATCC33804 (ם) by leaf clipping-inoculation. Inoculated plants were grown in the greenhouse at $25^{\circ} \mathrm{C} / 20^{\circ} \mathrm{C}$ (day/ night temperature). Bars indicate standard error $(n=3)$.

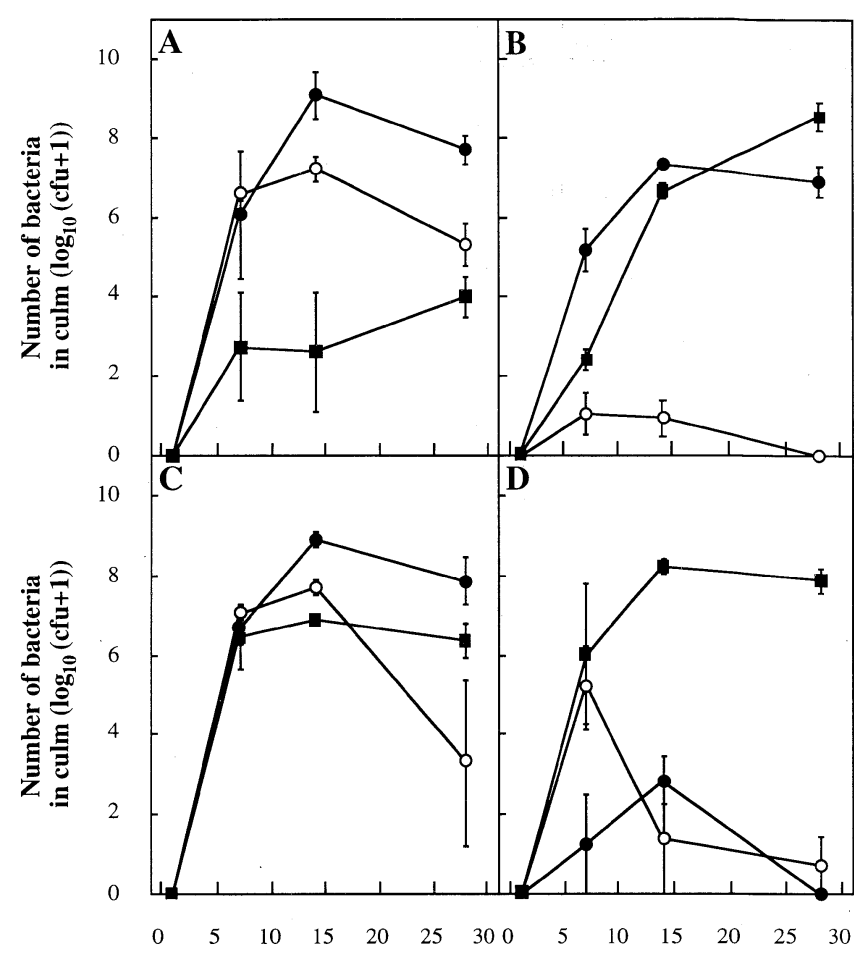

Days after inoculation

Days after inoculation

Fig. 2. Multiplication of strains of $X$. c. pv. poae in 5 $\mathrm{mm}$ sections of tissue from the lowest part of the culm of Poa species. Annual bluegrass ( $P$. annua) (A), rough bluegrass (P. trivialis) (B), supina bluegrass $(P$. supina) $(\mathrm{C})$ and big bluegrass $(P$. ampla) (D) were inoculated with $1.0 \times$ $10^{8} \mathrm{cfu} / \mathrm{ml}$ of bacterial suspension of JT-P192 (○), JT-P482 (๑) and ATCC33804 (ם) by leaf clipping-inoculation. Inoculated plants were grown in the greenhouse at $25^{\circ} \mathrm{C} / 20^{\circ} \mathrm{C}$ (day/ night temperature). Bars indicate standard error $(n=3)$.

Table 3. The symptoms produced on Poa species inoculated with 10 strains of $X$. $c$. pv. poae

\begin{tabular}{|c|c|c|c|c|c|c|c|c|c|c|}
\hline \multirow{3}{*}{$\begin{array}{c}\text { Plant } \\
\text { inoculated }\end{array}$} & \multicolumn{10}{|c|}{ Symptoms ${ }^{a)}$} \\
\hline & JT. & JT- & JT- & JT- & JT- & JT- & $\mathrm{MB}$ & MB & $\mathrm{MB}$ & ATCC \\
\hline & P192 & P195 & P196 & $\mathrm{P} 481$ & $\mathrm{P} 482$ & $\mathrm{P} 484$ & 218 & 245 & 291 & 33804 \\
\hline Annual bluegrass & $\mathrm{W} / \mathrm{C}$ & $\mathrm{W} / \mathrm{C}$ & $\mathrm{W} / \mathrm{C}$ & W & $\mathrm{W}$ & W & W & $\mathrm{W}$ & $\mathrm{W} / \mathrm{C}$ & W \\
\hline Rough bluegrass & - & - & - & $\mathrm{W}$ & $\mathrm{W}$ & $\mathrm{W}$ & $\mathrm{W}$ & W & - & W \\
\hline Supina bluegrass & $\mathrm{W} / \mathrm{C}$ & $\mathrm{W} / \mathrm{C}$ & $\mathrm{W} / \mathrm{C}$ & $\mathrm{W}$ & W & W & $\mathrm{W}$ & $\mathrm{W}$ & $\mathrm{W} / \mathrm{C}$ & $\mathrm{W}$ \\
\hline Big bluegrass & - & - & - & - & - & - & - & - & - & $\mathrm{W}$ \\
\hline
\end{tabular}

a) w/c, wilt and chlorosis; w, wilt only ; -, no symptom.

cation rate in the lowest part of the culm and aggressiveness was observed in all strain/plant combinations.

Microscopic observations 4 weeks after inoculation showed no bacteria in the lowest part of the culm of the other Poa species, Kentucky bluegrass, Canada bluegrass, sandberg bluegrass, bulbous bluegrass and alpine bluegrass.

\section{Symptoms of host plants}

Symptoms of four species of Poa inoculated with 10 strains of $X$. c. pv. poae were observed after inoculation
(Table 3), using the same plants as those used in the examination of bacterial multiplication. Four strains, JT-P192, JT-P195, JT-P196 and MB291, caused wilt and chlorosis on their host plants, annual bluegrass and supina bluegrass. Newly elongated leaves after infection were a discolored, pale yellow. Five strains, JT-P481, JT-P482, JT-P484, MB218 and MB245, caused wilt on annual bluegrass, rough bluegrass and supina bluegrass. Type strain of $X$. c. pv. poae, strain ATCC33804, caused wilt on annual bluegrass, rough bluegrass, supina blue- 
Table 4. Features of three groups of $X$. c. pv. poae

\begin{tabular}{llccc}
\hline \hline & $\begin{array}{c}\text { Representative } \\
\text { strain }\end{array}$ & $\begin{array}{c}\text { Symptoms on } \\
\text { host plants }\end{array}$ & $\begin{array}{c}\text { Pathogenicity to } \\
\text { rough bluegrass }\end{array}$ & $\begin{array}{c}\text { Pathogenicity to } \\
\text { big bluegrass }\end{array}$ \\
\hline Group 1 & JT-P192 & $\mathrm{W} / \mathrm{C}^{\text {a) }}$ & - b) & - \\
Group 2 & JT-P482 & $\mathrm{W}$ & + & - \\
Group 3 & ATCC33804 & $\mathrm{W}$ & + & + \\
\hline
\end{tabular}

a) w/c, wilt and chlorosis; w, wilt only.

b) + , showing pathogenicity; - , no pathogenicity.

grass and big bluegrass.

\section{DISCUSSION}

In this study, a disease index of $30 \%$ was used as a borderline between the presence and absence of typical symptoms. From this basis, strain JT-P192 caused symptoms in annual bluegrass, supina bluegrass and two cultivars of rough bluegrass (cv. Omega and the one originating in the UK.). However, JT-P192 was unable to spread to the lowest part of the culm of rough bluegrass after leaf clipping-inoculation. Because of this and the fact that ethylacetate extracts of culture filtrate of JT-P192 show phytotoxic activity (data not shown), strain JT-P192 may produce phytotoxic compounds in inoculated leaves of rough bluegrass, which cause the symptom-like effects on rough bluegrass.

In many cases, both compatible and incompatible bacteria multiply within the inoculation zone ${ }^{3,7}$. Robinson and Callow, studying the multiplication and spread of the xylem-invading xanthomonads $X . c . p v$. poae and $X$. oryzae pv. oryzae in rough bluegrass ${ }^{17)}$, reported that both compatible and incompatible bacteria could multiply within inoculation zones at similar rates but that their migration through plants varied. Compatible bacteria were distributed throughout host leaves, whereas the spread of incompatible bacteria was limited to the inoculation zone. Results from the present study showed that all strains were able to multiply in the inoculated leaf tips at the same rate but that multiplication in the lowest part of the culm varied with different plant/ strain combinations. In our method, the multiplication in the lowest part of the culm was correlated with bacteria distribution throughout the inoculated leaves, from inoculated tip to the lowest part of the culm. Using this pathogenicity trait of compatibility and the ability to distribute throughout leaves of host plants, strain JTP192 is compatible with annual bluegrass and supina bluegrass, strain JT-P482 is compatible with annual bluegrass, rough bluegrass and supina bluegrass, and type strain of $X$. c. pv. poae ATCC33804 is compatible with annual bluegrass, rough bluegrass, supina bluegrass and big bluegrass. $X$. c. pv. poae strains, however, are not compatible with the other tested plants, Kentucky bluegrass, Canada bluegrass, sandberg bluegrass, bulbous bluegrass and alpine bluegrass. Multiplication in the lowest part of the culm also corresponds to symptom appearance and its rate to disease severity.
Egli and Schmidt ${ }^{6}$ reported that $X$. c.pv. poae showed pathogenicity to the Poa genus, although considerable differences in susceptibility are found at the species level. In our previous report ${ }^{12)}$, we reported that the bacteriological properties of test strains, JT-P192, JTP482 and ATCC33804, were the same and that their host range was limited to the Poa genus. We now propose that $X . c$. pv. poae should be divided into three groups with the same pathovar status (Table 4). Group 1 causes pale yellow discoloration of new elongated leaf blades and wilt to annual bluegrass and supina bluegrass. Group 2 causes wilt to annual bluegrass, rough bluegrass and supina bluegrass. Group 3, which includes the type strain of $X . c$. pv. poae, causes wilt to annual bluegrass, rough bluegrass, supina bluegrass and big bluegrass. Representative strains of group 1 and group 2 are strain JT-P192 and strain JT-P482, respectively.

The authors wish to thank Dr. M. Konnai of Utsunomiya University and Dr. S. Savage of the Mycogen Corporation for providing us with the seeds of several species of Poa. We also thank Dr. M. Goto of Shizuoka University for his valuable advice for our study. We are also grateful to Ms. R. Hokabe for her valuable technical assistance.

\section{Literature cited}

1. Imaizumi, S., Nishino, T., Miyabe, K., Fujimori, T. and Yamada, M. (1997). Biological control of annual bluegrass (Poa annua L.) with a Japanese isolate of Xanthomonas campestris pv. poae (JT-P482). Biol. Control 8 : $7-14$.

2. Imaizumi, S., Tateno, A. and Fujimori, T. (1997). Effect of Xanthomonas campestris pv. poae (JT-P482) on the growth and seed production of annual bluegrass ( $P o a$ annua L.). J. Weed Sci. Tech. 42: 8-17.

3. Daub, M.E. and Hagedorn, D.J. (1980). Growth kinetics and interactions of Pseudomonas syringae with susceptible and resistant bean tissue. Phytopathology $70: 429-$ 436.

4. Dickens, R. (1979). Control of annual bluegrass (Poa annua) in overseeded bermudagrass (Cynodon sp.) golf greens. Weed Sci. 27 : 642-644.

5. Egli, T., Goto, M. and Schmidt, D. (1975). Bacterial wilt, a new forage grass disease. Phytopathol. Z. 82 : 111-121.

6. Egli, T. and Schmidt, D. (1982). Pathogenic variation among the causal agent of bacterial wilt of forage grasses. Phytopathol. Z. 104 : 138-150. 
7. Gross, D.C. and De Vay, J.E. (1977). Population dynamics and pathogenesis of Pseudomonas syringae in maize and cowpea in relation to in vitro production of syringomycin. Phytopathology $67: 475-483$.

8. Johnson, B.J. (1994). Biological control of annual bluegrass with Xanthomonas campestris pv. poannua in bermudagrass. HortScience 29 : 659-662.

9. Kauffman, H.E., Reddy, A.P.K., Hesieh, S.P.Y. and Merca, S.D. (1973). An improved technique for evaluating resistance of rice varieties to Xanthomonas oryzae. Plant Dis. Rep. 57 : 537-541.

10. Miyabe, K., Imaizumi, S., Goto, M. and Takikawa, Y. (1993). Bacterial wilt of Poa annua caused by a pathovar Xanthomonas campestris in Japan. Ann. Phytopathol. Soc. Jpn. 59 : 309 (Abstr. in Japanese).

11. Nishino, T., Imaizumi, S. and Yamada, M. (1994). Xanthomonas campestris pv. "poannua" isolated from symptomless annual bluegrass (Poa annua). Ann. Phytopathol. Soc. Jpn. 60 : 366 (Abstr. in Japanese).

12. Nishino, T., Imaizumi, S., Miyabe, K., Yamada, M. and Goto, M. (1995). Xanthomonas campestris pv. poae as the causal agent of wilt symptoms on annual bluegrass in Japan. Ann. Phytopathol. Soc. Jpn. $61: 555-561$.

13. Nishino, T. and Fujimori, T. (1996). Influence of inoculum concentration, temperature and humidity on the disease of annual bluegrass caused by Xanthomonas campestris pv. poae JT-P482. Ann. Phytopathol. Soc. Jpn. 62 : 492-494

14. Nishino, T., Morita, K. and Fujimori, T. (1997). Fate of Xanthomonas campestris pv. poae, a biological control agent for annual bluegrass, in soil. J. Pestic. Sci. 22 : 326-330.

15. Osada, T. (1989). Illustrated Grasses of Japan, Heibon! sha, Tokyo, pp. 158-205 (in Japanese).

16. Roberts, D.L., Vargas, J.M., Jr. and Detweiler, R. (1985). Occurrence of bacterial wilt on Poa annua and other turfgrasses. Phytopathology 75 : 1289 (Abstr.).

17. Robinson, J.N. and Callow, J.A. (1986). Multiplication and spread of pathovars of Xanthomonas campestris in host and non-host plants. Plant Pathol. 35 : 169-177.

18. Van Den Mooter, M., Steenackers, M., Maertens, C., Gossele, F., De Vos, P., Swings, J., Kersters, K. and De Ley, J. (1987). Differentiation between Xanthomonas campestris pv. graminis (ISPP list 1980), pv. phleipraten sis (ISPP list 1980) emend., pv. poae Egli and Schmidt 1982 and pv. arrhenatheri Egli and Schmidt 1982, by numerical analysis of phenotypic features and protein gel electrophoregrams. J. Phytopathol. 118 : 135-156.

19. Zhou, T. and Neal, J.C. (1995). Annual bluegrass (Poa annua) control with Xanthomonas campestris pv. poannua in New York State. Weed Technol. 9 : 173-177.

\section{和 文 摘 要}

西野友規・藤森 嶺: Xanthomonas campestris pv. poae の $P o a$ 属植物に対する病原性の多様性

日本およびアメリカで分離されたスズメノカタビラに萎ちょ う症状を引き起こす Xanthomonas campestris pv. poaeのうち 任意に選抜した 9 菌株と X. c . pv. poae の標準菌株である ATCC33804 株を用いて, 9 種 23 系統のP Poa 属植物に対する病 原性を，(1) 病気を引き起こすか，(2) 植物内で増殖・移行でき るか, (3) 宿主植物の病徴はどのようなものか, という 3 項目に ついて調査した。剪葉接種法により接種試験を行ったところ,す べての菌株はすべての供試植物の接種部位において増殖した が，地際部での細菌の増殖にはそれぞれの組み合わせにおいて 差がみられ, 病徴の有無と地際部での細菌の増殖には相関関係 が存在していた。その結果, X. c. pv. poae はPoa 属植物に対 する病原性の違いから 3 グループに区別されることが明らかと なった。すなわち $X . c . p v$. poae は, スズメノカタビラと supina bluegrassに対して病原性を示し，その病徴が萎ちょう症状と葉 の黄化症状である JT-P192 株に代表されるグループ1，スズメ ノカタビラ, rough bluegrass, supina bluegrass に対して萎ち ょう症状のみを引き起こす JT-P482 株に代表されるグループ 2, そしてズズメノカタビラ, rough bluegrass, supina bluegrass, big bluegrass に対して萎ちょう症状のみを引き起こす 標準菌株である ATCC33804 に代表されるグループ 3 に区別さ れる。 